\title{
Analysis of the connections between hydromorphological conditions and biocenotic diversity on the example of the Zwoleńka River
}

\author{
KAROLINA SAWA, ZBIGNIEW POPEK \\ Department of Hydraulic Engineering, Warsaw University of Life Sciences - SGGW
}

\begin{abstract}
Analysis of the connections between hydromorphological conditions and biocenotic diversity on the example of the Zwolenka River. The paper presents the evaluation of ecological status of two hydromorphologically diverse stream reaches of the Zwoleńka River. The studied sections of $500 \mathrm{~m}$ length are localized in a natural river-bed (Siekierka) and river-bed transformed due to a regulation (Zwoleń). The hydromorphological assessment of the stream has been performed by means of River Habitat Survey method (RHS). Level of habitat transformation has been determined with a help of numerical indices of the method: HMS and HQA; their naturalness has been also evaluated. Biotic conditions have been evaluated on a base of macrophyte river assessment and benthos macroinvertebrates. Macroinvertebrates have been determined to the level of family and following water quality indices have been also calculated: BMWP-Pl, ASPT, and EPT\%. Value of BMWP-Pl has revealed that waters within the natural section of the stream could be qualified to the II grade of quality, while those in transformed section - to III grade. Moreover, it has been found that EPT\% indicator has been much higher in non-transformed section. Evaluation of examined stream sections on a basis of Macrophyte Index for Rivers (MIR) has revealed that the numerical value of the indicator has been almost unaffected by the river-bed transformation degree. In both cases, examined fragments of the stream have been qualified as the II grade. In addition, physicochemical determinations of water have been carried out. However, no substantial differences of water quality, that could influence
\end{abstract}

on biocenotic diversity of those habitats, between analyzed stream sections, have been recorded. Content of organic particles in sediments as well as granulation characteristics have been determined as well.

Therefore, the present research has allowed to learn some relationships between abiotic and biotic elements of a small lowland river, which can be an initial point for further studies.

Key words: river hydromorphology, macroinvertebrates, macrophytes, ecological status of river.

\section{INTRODUCTION}

Up to 2003, water quality assessment in Poland had been made namely in reference to its usefulness for farm utilization. However, along with increasing anthropogenic pressure and decreasing water quality, the scope of indicators and evaluation criteria for water quality have been enhanced. In order to reduce the intensifying surface waters degradation within all European Union, the attempt to water resources evaluation has been altered, which was formulated in Water Framework Directive, according to which the ecological status should be assessed on a base of biological elements, while physicochemical and hydromorphological parameters have 
to play only a supportive roles (Andynkiewicz-Piragas et al. 2006).

British River Habitat Survey method (RHS) has been used in present study to evaluate the habitat character and the flow morphological quality; it makes possible to quantitatively express the morphological features in a form of synthetic HMS and HQA indicators (Szoszkiewicz 2009). Biotic elements subject to assessment are macrophytes and macroinvertebrates. Macrophyte Method for River Assessment (MMOR) is based on a quantitative and qualitative evaluation of aqueous plant species composition and allows for calculating the synthetic index of Macrophyte Index for Rivers (MIR) (Szoszkiewicz et al. 2010).

The present research aimed at determining the ecological status of small river within natural and transformed sections using various valorization methods for elements of biotic environment and hydromorphological features of the river-bed and river valley.

\section{CHARACTERIZATION OF STUDIED AREA}

The Zwoleńka River is the right tributary of Vistula river and its estuary is localized near Lucimia village. Total area of the stream catchment is $230.1 \mathrm{~km}^{2}$, while its length amounts to $34.1 \mathrm{~km}$ (Atlas podziału... 1984; 2005). Forests occupy $19 \%$, permanent green lands about $7 \%$, and arable lands $72 \%$ of its catchment area (Jadczyszyn et al. 2011). Soil covering the catchment is built of loams and sands on marls and cretaceous sandstones; very acidic $(\mathrm{pH}<4.5)$ and acidic soils ( $\mathrm{pH} 4.6-5.5$ ) prevail. The catchment area is characterized by weak sandy soils with low level of organic matter and low usefulness for plant production.

The Zwoleńka River is not uniform in reference to its bed transformation. Both fragments similar to natural ones and regulated to different degrees can be found. The stream is typical small lowland river that can serve as an object for studies upon evaluating the influence of anthropogenic transformations of riverbed on diversity of biocenotic composition of macrophyte vegetation and macrobenthos. A detailed recognition of a current ecological status of the river is important determinant for planning the restoration works.

The river reach near Siekierka Stara village was selected as the section, the features of which are similar to natural ones. Selected transformed (regulated) section is localized directly out of Zwolen city limits. Localization of these study points is presented in Figure 1.

Analysis of land use within 50 meter bands from the stream's banks, was performed for the study section of $500 \mathrm{~m}$ length. Figure 2 presents the land use maps for natural (Siekierka) and regulated test stand (Zwoleń).

Majority of analyzed area in test stand Siekierka $(69.4 \%)$ is occupied by green lands, whereas forests cover remarkable area $(46.0 \%)$ in section Zwoleń. Waters $(13.3 \%)$, mainly in a form of natural reservoirs near the stream, are present within natural fragment. Arable lands are quite numerous (about $20 \%$ ) in regulated stand. Presence of forest cover in a form of clusters scattered along the stream is also very common. The percentage of particular performance forms of lands adjacent to studied stream is presented in Figure 3. 

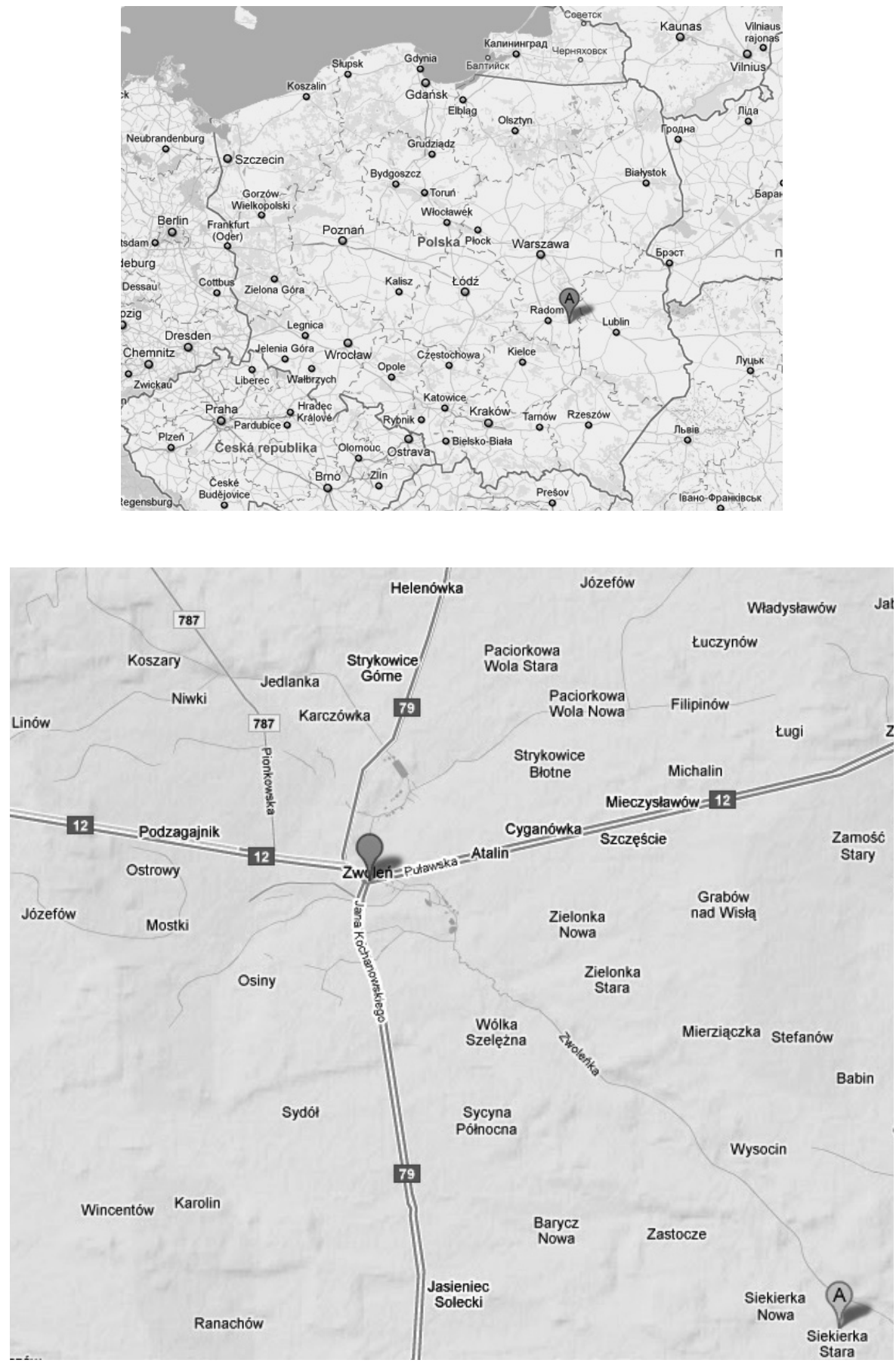

FIGURE 1. Localization of analyzed positions 
a)

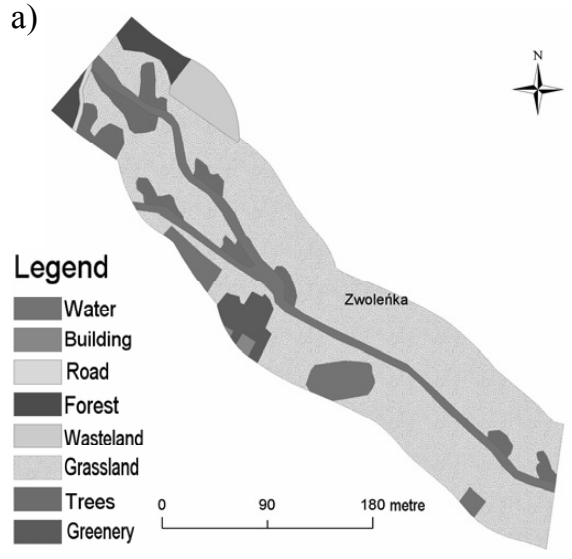

b)

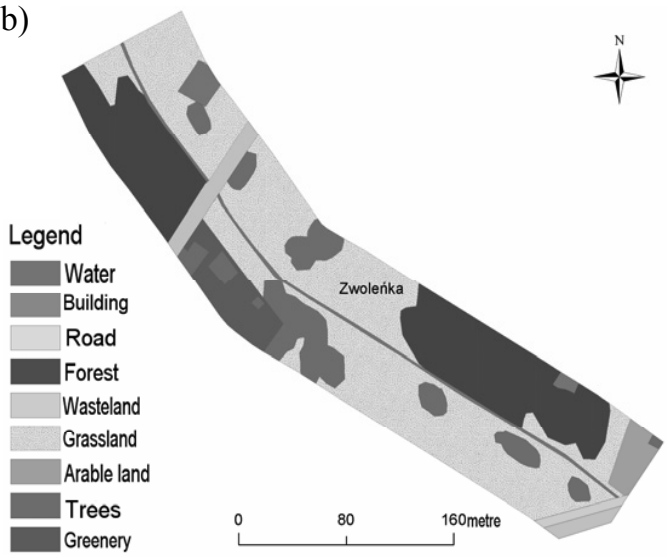

FIGURE 2. Maps of land use for analyzed sections: a) Siekierka i b) Zwoleń

a)

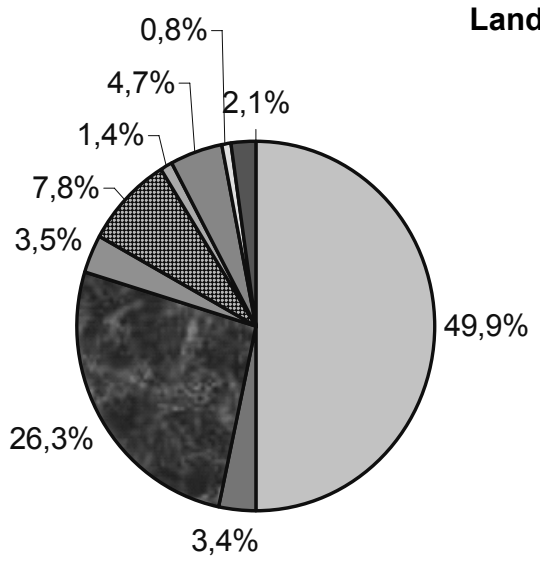

\begin{tabular}{|l|}
\hline$\square$ Grassland \\
$\square$ Water \\
$\square$ Forest \\
$\square$ Road \\
⿴囗rees \\
$\square$ Building \\
$\square$ Greenery \\
$\square$ Wasteland \\
$\square$ Arable land \\
\hline
\end{tabular}

b)

\section{Land use - Zwoleń}

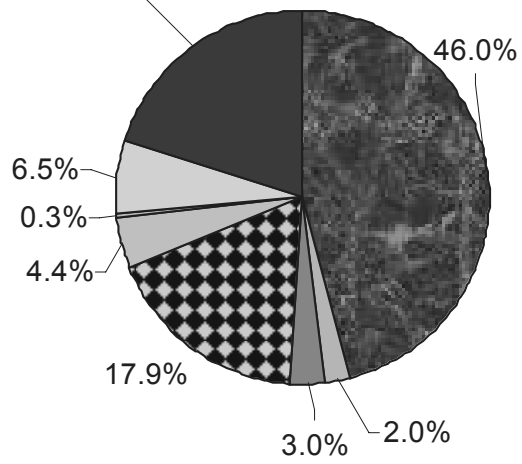

\begin{tabular}{|l|}
\hline$\square$ Forest \\
$\square$ Road \\
$\square$ Water \\
$\square$ Trees \\
$\square$ Wasteland \\
$\square$ Greenery \\
$\square$ Grassland \\
$\square$ Arable land
\end{tabular}

FIGURE 3. Diagram of land use for analyzed sections: a) Siekierka i b) Zwoleń 


\section{HYDROMORPHOLOGICAL CHARACTERISTICS}

The Zwoleńka river-bed is of variable character: tortuous or meandering flow within natural, while rectilinear with small number of circular bends within regulated sections. Fragmentary river regulation took place in 70's and since then the river-bed morphology prominently changed. It was influenced on by natural factors such as plant succession, beaver's activity, or water flow, as well as anthropogenic reasons, i.e. no maintenance and damage of river banks (Wasilewicz 2007).

Hydromorphological evaluation was carried out according to River Habitat Survey method (RHS). Studied section of $500 \mathrm{~m}$ length was subject to synthetic assessment as well as detailed examination in 10 uniformly distributed control profiles. That examination made possible to collect about 400 parameters. The detailed analysis took into account following elements: physical attributes of embankments and river-bed, performance and structure of vegetation, as well as groups of aquatic plants. Furthermore, synthetic analysis included elements that were not considered during the previous stage of study. In addition, the description was completed with the valley performance characteristics as well as river-bed morphological parameters. The RHS method also gives the opportunity to evaluate hydromorphological parameters in a form of following indices: HMS - degree of habitat transformation, and HQA - indicating the habitat naturalness (Szoszkiewicz et al. 2011). The HQA value may fall within 0 to 136 , while that of HMS within the range of 0 to 100 . High HMS values indicate a strong transfor- mation of a given section, while low - negligible degree of river transformation. The higher HQA value, the greater diversity of natural morphological elements within analyzed river section.

Value of HQA index amounted to 82 and HMS to 3 for Siekierka section, whereas for Zwoleń section, those indices were as follows: $\mathrm{HQA}=55$ and $\mathrm{HMS}=11$ (Tab.1). Greater diversity of natural morphological elements of the embankment and river-bed such as presence of eroding and stable cutbanks, meander and sandbanks, were observed in Siekierka section. Only eroding cutbanks were present at Zwolen stand and their number was much lower than at natural one.

TABLE 1. Comparison of HMS and HQA indexes

\begin{tabular}{|c|c|c|}
\hline Index & Siekierka & Zwoleń \\
\hline HMS & 3 & 11 \\
\hline HQA & 82 & 55 \\
\hline
\end{tabular}

Hydraulic parameters such as flow-rate or flow depth affect the type of material accumulated at the bottom of a river, thus indirectly influencing on covering the bottom with plants as well as species composition of macroinvertebrates. General hydromorphological parameters were determined at 10 cross-sections localized within 500 meter long river reach. Mean depths and widths of river-bed were similar at both stands. The river-bed width to mean depth ratio varied in both sections, which indicates considerable differentiation of these parameters. Maximum to mean depth ratios were also different for each section. The flow-rates were very low, yet the value was about 10 times higher at Siekierka rather than Zwoleń stand. Laminar flow dominated 
TABLE 2. Hydromorphology parameters for Zwoleń and Siekierka sections

\begin{tabular}{|l|c|c|c|c|c|}
\hline Section & $\begin{array}{c}\text { Average depth } \\
\mathrm{h}_{\text {sr }}[\mathrm{m}]\end{array}$ & $\begin{array}{c}\text { River bed width } \\
\mathrm{B}[\mathrm{m}]\end{array}$ & $\begin{array}{c}\text { Average volume } \\
{\left[\mathrm{m}^{3} / \mathrm{s}\right]}\end{array}$ & $\mathrm{B} / \mathrm{h}_{\text {sr }}$ & $\mathrm{h}_{\text {max }} / \mathrm{h}_{\text {sr }}$ \\
\hline Zwoleńka-Zwoleń & $0.35-0.62$ & $4.9-7.0$ & $0.008-0.025$ & $6.31-18.4$ & $0.77-2.08$ \\
\hline Zwoleńka-Siekierka & $0.34-0.73$ & $4.7-8.0$ & $0.081-0.195$ & $6.78-20.7$ & $1.24-1.62$ \\
\hline
\end{tabular}

although presence of rapid flow was also recorded within Siekierka section. The flow at majority of Zwoleń section was impossible to record. All above discussed parameters are presented in Table 2.

\section{PHYSICOCHEMICAL ANALYSIS}

Physicochemical analysis of water quality was carried out for every test stand selected. According to Decree of Ministry of the Environment from 20.08.2008 on a ways for status classification of uniform parts of surface waters (DzU No 162, pos. 1008), all evaluable parameters, excluding dissolved oxygen, were within limiting range corresponded to the I grade of water quality at both studied stands. Low levels of dissolved oxygen can result from the low flow-rate and shallow water depth at control points, which favors faster water warming, thus oxygen release. Table 3 presents results of chromatographic analysis for particular stands.

Eutrophication and anthropogenic contamination have the significant effects on

TABLE 3. Result of physical and chemical analysis for Zwoleń and Siekierka sections

\begin{tabular}{|c|c|c|c|}
\hline Parameter & Siekierka & Zwoleń & Water quality class \\
\hline Coordinates & $\begin{array}{l}\text { N51 } 1744.3 \\
\text { E021 } \\
414\end{array}$ & $\begin{array}{l}\text { N51 } 22231.2 \\
\text { E021 } 3530.9\end{array}$ & - \\
\hline Temperature $\left[{ }^{\circ} \mathrm{C}\right]$ & 19.700 & 20.000 & I \\
\hline $\mathrm{pH}$ & 7.930 & 7.140 & I \\
\hline Electrolytic conductance $[\mu \mathrm{S} / \mathrm{cm}]$ & 525.000 & 306.000 & I \\
\hline $\mathrm{O}_{2}[\mathrm{mg} / \mathrm{l}]$ & 6.240 & 6.110 & II \\
\hline Fluoride [mg F/l] & 0.033 & 0.181 & Not classiffied \\
\hline Bromine [mg Br/l] & 0.017 & 0.011 & Not classiffied \\
\hline Chloride [mg Cl/l] & 8.357 & 8.898 & $\mathrm{I}$ \\
\hline $\mathrm{NO}_{3}\left[\mathrm{mg} \mathrm{NO}_{2} / \mathrm{l}\right]$ & 0.011 & 0.033 & Not classiffied \\
\hline $\mathrm{NO}_{2}\left[\mathrm{mg} \mathrm{NO}_{3} / 1\right]$ & 0.037 & 2.382 & $\mathrm{I}$ \\
\hline Ortophosphorate $\left[\mathrm{mg} \mathrm{PO}_{4} / \mathrm{l}\right]$ & 0.057 & 0.057 & Not classiffied \\
\hline Phosphatic phosphorus [mg P/l] & 0.019 & 0.019 & Not classiffied \\
\hline Sulphate $\left[\mathrm{mg} \mathrm{SO}_{4} / \mathrm{l}\right]$ & 3.390 & 20.292 & $\mathrm{I}$ \\
\hline Lithium [mg Li/l] & 0.010 & 0.008 & Not classiffied \\
\hline Sodium $[\mathrm{mg} \mathrm{Na} / \mathrm{l}]$ & 23.006 & 7.289 & Not classiffied \\
\hline Ammonia $\left[\mathrm{mg} \mathrm{NH}_{4} / \mathrm{l}\right]$ & 0.095 & 0.082 & $\mathrm{I}$ \\
\hline Potassiun [mg K/l] & 3.328 & 1.682 & Not classiffied \\
\hline Magnesium [mg Mg/l] & 11.042 & 6.370 & I \\
\hline Calcium [mg Ca/l] & 84.573 & 58.742 & $\mathrm{I}$ \\
\hline
\end{tabular}


the biocenotic composition. Contaminants originated from agricultural areas have no substantial impact on water quality due to the presence of a barrier between rivers and croplands, mainly in a form of tall vegetation buffers. The plant belts make contamination supply from ground waters and surface waters from green lands difficult. Low biogens concentration is associated with their use to build the biomass by macrophytes during the vegetation season. No remarkable differences in water quality affecting the biocenotic diversity of these stands, were observed between analyzed studied stream sections.

\section{STUDIES UPON \\ MACROINVERTEBRATES}

Invertebrate fauna significantly determines the stability of river ecosystems. A great diversity of microhabitats is present in rivers, even within short (about $100 \mathrm{~m}$ ) river section. Biodiversity of macroinvertebrates is affected by many elements, among which there are type of a subsoil, flow-rate, and physicochemical conditions (Bylak and Kukuła 2007).

Polish version of Biological Monitoring Working Partly (BMWP-Pl) was calculated for selected stands. It is based on determining the macroinvertebrate taxa - up to the family level - in a river and assigning the corresponded point score that is used for calculating the index value. The ASPT indicator - Average Score Per Talon (that is average indicator of water quality) is calculated as well. Value of ASPT is calculated by dividing the BMWP value by the number of taxa found in a given sample. Numbers of taxa from mayfly (Ephemeroptera), stonefly (Plecoptera), and caddisfly (Trichoptera) orders are of a fundamental importance for indicating the status of environment. Therefore, the ETP\% index is calculated for these taxa (Grabowski et al. 2006).

Samples for determinations were collected from 100 meter long stream sections localized within earlier selected 500 meter stands. Differences of the indices values between the stream and the embankments were negligible or there were no differences at all. In Siekierka stand, value of BMWP-Pl was 77, which was higher than in Zwolen stand (56). The ASPT index value was similar in both stands and amounted to about 5. Instead, remarkable difference was prominent in the case of ЕРT\% index, that was about 7 times higher in Siekierka than Zwoleń stand (Tab. 4).

Assessment of water quality on a base of benthos macroinvertebrates revealed that the section Zwolen was qualified to III grad, while section Siekierka to II grade.

Lower morphological diversity of a river leads to the decrease in biodiversity. Mayflies (Ephemeroptera) show

TABLE 4. Comparison of BMWP-Pl, ASPT and ETP\% indexes for Zwoleń and Siekierka sections

\begin{tabular}{|l|c|c|c|}
\hline Section & BMWP-Pl index & ASPT index & EPT\% index \\
\hline Zwoleńka-Zwoleń - river bank & 56 & 5.1 & 7.3 \\
\hline Zwoleńka-Zwoleń - stream & 56 & 5.1 & 6.2 \\
\hline Zwoleńka-Siekierka - river bank & 77 & 5.5 & 45.9 \\
\hline Zwoleńka-Siekierka - stream & 72 & 5.5 & 47.7 \\
\hline
\end{tabular}


great sensitivity towards environmental contamination. Numerous representatives of two families at Siekierka stand Baetidae and Leptophlebiidae - whereas exclusively the representatives of more tolerant Baetidae family were found at Zwoleń stand, although their number was small. Individuals of Oligochaeta order were present at both stands. Their abundant occurrence is associated with the presence of Diptera (Chironomidae) representatives at Zwolen stand and representatives of Hirudinea within Siekierka section, for which Oligochaeta are the food base. Massive occurrence of Gastropoda order individuals was observed at both stands, which can be attributed to low water flow-rate and sandy subsoils in both sections. The Trichoptera order larvae were met only within natural section Siekierka, while Emphemeroptera and Plecoptera individuals were found within both sections, yet their populations were much higher in natural stand.

\section{STUDIES UPON MACROPHYTES}

The macrophyte vegetation compositions greatly depends on hydraulic conditions within a river-bed; among which there are: flow-rate, flow depth, or presence of various river-bed structures.

Macrophyte Method for River Assessment (MMOR) is based on both qualitative and quantitative evaluation of species composition of plants rooted in waters. Applying the MMOR allows for determining the advancing of the flowing waters degradation process, namely in reference to their trophy. Knowledge upon the degree of a given macrophyte sensitivity towards contamination makes possible to determine the average contamination level in field during the whole vegetation season on a base of only a single examination. Macrophyte Index for Rivers (MIR) is the numerical indicator of MMOR and when compared to referential values, it allows for evaluating the ecological status according to assumptions of the Water Framework Directive. MIR takes into account 153 macrophyte taxa, to which corresponded values of indicator number (L) and weight coefficient (W) are assigned. In addition, it is necessary to establish the coverage coefficient (P) for particular species. Qualification of studied sections to particular class of ecological status is performed using Coefficient of Ecological Quality (WJE), that takes into account the type of a river, the lowest observed value of MIR, as well as MIR value under referential conditions (Szoszkiewicz et al. 2010).

Presence of 22 macrophyte species were recorded both in Siekierka and Zwoleń stands, including 12 ones occurred within both sections. Most of those species prefer mesotrophic habitats, which is proved by $L$ number oscillating between 1 (value characteristic for eutrophic species) and 10 (feature of oligotrophic species). The weight coefficient $\mathrm{W}$ indicates the scope of the species' ecological tolerance. All present species showed poor or moderate tolerance towards contamination; only a single stenotopic species was reported (Ceratophyllum submersum) (Tab. 5).

Calculated value of the macrophyte indicator allows for concluding that the ecological status of stream Zwoleńka at both sections can be counted as good (II grade). The MIR value in both studied stands were very close (Tab. 6), which indicates that the river-bed transformation 
TABLE 5. Macrophytes species occured in Zwoleń and Siekierka sections

\begin{tabular}{|c|c|c|c|c|c|c|c|c|c|}
\hline Species & Zwoleń & Siekierka & $\mathrm{L}$ & W & Species & Zwoleń & Siekierka & $\mathrm{L}$ & $\mathrm{W}$ \\
\hline ALGE & & & & & MONOCOTS & & & & \\
\hline Enteromorphora sp. & $x$ & & 1 & 2 & Alisma plantago-aquatica & $x$ & $x$ & 4 & 2 \\
\hline PTERIDOPHYTES & & & & & Carex acutiformis & & $x$ & 4 & 1 \\
\hline Equisetum fluviatile & $x$ & & 6 & 2 & Carex riparia & $x$ & $x$ & 4 & 2 \\
\hline DICOTYLEDONS & & & & & Elodea canadensis & $x$ & $x$ & 5 & 2 \\
\hline Berula erecta & $\times$ & $\times$ & 4 & 2 & Glyceria maxima & $\times$ & $x$ & 3 & 1 \\
\hline Ceratophyllum submersum & $x$ & & 2 & 3 & Iris pseudacorus & & $x$ & 6 & 2 \\
\hline Lysimachia vulgaris & $x$ & $x$ & 4 & 1 & Lemna minor & $x$ & $x$ & 2 & 2 \\
\hline Myosotis palustris & $x$ & & 4 & 1 & Lemna trisulca & & $x$ & 4 & 2 \\
\hline Nuphar lutea & & $x$ & 4 & 2 & Phalaris arundinacea & $x$ & $x$ & 2 & 1 \\
\hline Peucedanum palustre & $x$ & & 5 & 2 & Sagittaria sagittifolia & & $x$ & 4 & 2 \\
\hline Polygonum amphibium & $x$ & & 4 & 1 & Sparganium erectum & & $x$ & 3 & 1 \\
\hline Polygonum hydropiper & $x$ & & 3 & 1 & Lythrum salicaria & $x$ & & - & - \\
\hline Polygonum persicaria & & $x$ & 2 & 2 & Phragmites australis & $x$ & $x$ & - & - \\
\hline Rumex hydrolapathum & $x$ & $x$ & 4 & 1 & Galium uligiosum & $x$ & & - & - \\
\hline Sium latifolium & & $x$ & 7 & 1 & Solanum dulcamara & $x$ & & - & - \\
\hline Stachys palustris & $x$ & $x$ & 2 & 1 & Lycopus europeaus & & $\times$ & - & - \\
\hline \multirow[t]{3}{*}{ Veronica beccabunga } & $\times$ & $\times$ & 4 & 1 & Bidens triparia & & $x$ & - & - \\
\hline & & & & & Scutellaria galericulata & & & - & - \\
\hline & & & & & Peucedanum palustre & & & - & - \\
\hline
\end{tabular}

TABLE 6. Comparison of MIR and WJE indexes for Zwoleń and Siekierka sections

\begin{tabular}{|l|c|c|}
\hline Section & MIR index & WJE index \\
\hline Zwoleńka-Zwoleń & 36.15 & 0.68 \\
\hline Zwoleńka-Siekierka & 36.56 & 0.69 \\
\hline
\end{tabular}

had no substantial influence on the species composition of macrophyte vegetation.

\section{BOTTOM SEDIMENTS ANALYSIS}

Characterization of bottom sediments was carried out using laser analyzer Mastersizer (Malvern Instruments Ltd.), that makes possible to determine the particle dimensions ranging from 0.05 to $550 \mu \mathrm{m}$. The device works due to laser diffraction phenomenon, i.e. uses the light scattering. Particles of given dimensions, when lighted with laser, scatter the light beam and fall onto the detector measuring the light divergence angle. The measure of that angle is inversely proportional $t$ the particle size (Banasik and Hejduk 2005).

Characteristic diameters $\mathrm{d} 10, \mathrm{~d} 50$, and d90 were much smaller for sediments collected from Zwoleń rather than Siekierka section (Tab. 7). The feature is associated with the flow conditions within regulated section, where very low flow-rates are present, which favors the accumulation of fine rubble fractions. Sand is a dominating component at the bottom of both studied sections. Content of organic parts

TABLE 7. Specification of characteristic diameter for analyzed sediments

\begin{tabular}{|c|c|c|}
\hline \multirow{2}{*}{$\begin{array}{c}\text { Characteristic diameter } \\
{[\mu \mathrm{m}]}\end{array}$} & \multicolumn{2}{|c|}{ Section } \\
\cline { 2 - 3 } & Siekierka & Zwoleń \\
\hline $\mathrm{d} 10$ & 99 & 8 \\
\hline $\mathrm{d} 50$ & 236 & 55 \\
\hline $\mathrm{d} 90$ & 415 & 211 \\
\hline
\end{tabular}


in study section Siekierka was 3.28\%, while in Zwoleń section - 1.61\%.

\section{CONCLUSIONS}

Results from performed research allow for drawing following conclusions:

- Evaluation of the transformation and naturalness degree of studied sections of the Zwoleńka River carried out by means of RHS method revealed that the natural fragment in Siekierka stand, where no anthropogenic modifications were made (HMS $=2$ ), was characterized by greater diversity of habitat features $(\mathrm{HQA}=82)$ than regulated section in stand Zwoleń (HMS $=11$, HQA $=55$ ). Thus, it was confirmed that RHS method gave a proper and precise tool for evaluating the environment value taking into account mainly hydromorphological features of the flow.

- Physicochemical analysis of water results did not reveal any significant quality differences of studied river sections, which would affect their diversity in a biocenotic view. In both sections, waters can be qualified to II grade of quality.

- Macrophyte vegetation did not reveal any substantial sensitivity towards habitat transformations. Value of MIR were similar in both studied sections, which resulted from similar species composition of macrophyte vegetation. Presence of particular macrophyte species depends greatly on hydraulic conditions found in a river-bed, as well as shading by tall plants grown within the embankment zone. Abiotic conditions were similar in both studied stands, and
MIR value indicated quite good ecological status of the stream (II grade).

- Results from studies upon invertebrate fauna present in bottom sediments revealed that examined stream sections prominently differed referring to the ecological status. Larger number of macroinvertebrate families as well as occurrence of taxa more sensitive towards contamination in natural rather than regulated section. Taking into account the BMWP-Pl value, ecological status of natural river reach (Siekierka) was qualified as good (II grade), while the regulated one (Zwoleń) as moderate (III grade).

- Achieved results of the stream ecological status evaluation proved that BMWP-Pl seems to be more sensitive indicator of a river-bed transformation than MIR. Moreover, it was found that RHS method is properly sensitive towards habitat transformation, which allows for a right assessment of the environmental quality on a base of HMS and HQA.

- Considering the evaluation of all studied environmental elements (biological, physicochemical, and hydromorphological), the ecological status of Siekierka section can be qualified as good, whereas that of Zwolen section as moderate.

\section{REFERENCES}

ANDYNKIEWICZ-PIRAGAS M., KRZEMIŃSKA A., TARNOWSKI K., WRÓBLEWSKI T. 2006: Charakterystyka i zróżnicowanie parametrów hydromorfologicznych w rzece nizinnej na przykładzie Smortawy [Characteristics and diversity of hydromorphological parameters in the example of lowland river 
Smortawa]. Infrastruktura i Ekologia Terenów Wiejskich, Nr 4/3, p. 17-24.

Atlas podziału hydrograficznego Polski 1986: [Hydrographic Atlas of Polish Division].Tom II, z. 1. Wydawnictwa Geologiczne, Warszawa. Atlas podziału hydrograficznego Polski 2005: [Hydrographic Atlas of Polish Division]. Seria „Atlasy”. IMGW, Warszawa.

BANASIK K., HEJDUK L. 2005: Badania granulometrii rumowiska unoszonego w małej rzece nizinnej [Grain size distribution of suspended sediment in small lowland river]. Acta Agrophysica, 5(2), 253-262.

BYLAK A., KUKUŁA K. 2007: Monitoring naturalnej i uregulowanej części potoku podgórskiego z wykorzystaniem bentosu [Monitoring of natural and regulated part of stream using benthos]. Zeszyty Naukowe Katedry Biologii Środowiska Uniwersytetu Rzeszowskiego, Nr 9, 25-30.

GRABOWSKI M., JABŁOŃSKAA., JAŻDŻEWSKI K., KLUKOWSKA M., KŁONOWSKAOLEJNIK M., MAJECKI J., PIECHOCKI A., PRZEWOŹNY M., SZCZĘSNY B., WIEDEŃSKA J., TOŃCZYK G. (red.) 2006: Klucz do oznaczania makrobezkręgowców bentosowych dla potrzeb oceny stanu ekologicznego wód powierzchniowych w Polsce [The key to determining macroinvertebrates for the assessment of ecological status of surface waters in Poland]. Uniwersytet Łódzki, Katedra Zoologii Bezkręgowców i Hydrobiologii. Łódź.

JADCZYSZYN T., IGRAS J., NOWOCIEŃ E., PODOLSKI B., WAWEL R. 2011: Charakterystyka gleb zlewni rzeki Zwoleńki [Characteristic of soils in Zwoleńka River watershed]. Przegląd Naukowy - Inżynieria i Kształtowanie Srodowiska nr 52: 119-129.

SZOSZKIEWICZ K., ZGOŁA T., GIEŁCZEWSKI M., STELMASZCZYK M. 2009: Zastosowanie metody River Habitat Survey do waloryzacji hydromorfologicznej i oceny skutków planowanych działan renaturyzacyjnych [Application of River Habitat Survey method for hydromorphological assessment of rivers and for evaluating potential restoration efforts]. Nauka Przyroda Technologie, Tom 3, Zeszyt 3, 1-9.

SZOSZKIEWICZ K., ZBIERSKA J., JUSIK S., ZGOŁA T. 2010: Makrofitowa Metoda Oceny Rzek [Macrophyte Survey on Rivers]. Bogucki Wydawnictwo Naukowe, Poznań.
SZOSZKIEWICZK., ZGOŁAT., JUSIK S., HRYCJUSIK B., DAWSON F., RAVEN P. 2011: Hydromorfologiczna ocena wód płynących [River Habitat Survey]. Poznań-Warrington.

WASILEWICZ M. 2007: Zróżnicowanie warunków morfodynamicznych i przyrodniczych w naturalnym i przekształconym korycie Wkry [Morphodynamic and ecological conditions diversity in natural and regulated channel of Wkra River]. Rozprawa doktorska, Katedra Inżynierii wodnej i Rekultywacji środowiska, SGGW, Warszawa.

Streszczenie: Analiza zwiazku warunków hydromorfologicznych ze zróżnicowaniem biocenotycznym na przykładzie rzeki Zwoleńki. W artykule przedstawiono ocenę stanu ekologicznego dwóch zróżnicowanych pod względem hydromorfologicznym odcinków rzeki Zwoleńki. Odcinki badawcze o długości $500 \mathrm{~m}$ zlokalizowano w korycie naturalnym (Siekierka) i przekształconym w wyniku regulacji (Zwoleń). Ocena hydromorfologiczna rzeki została wykonana przy użyciu metody River Habitat Survey (RHS). Za pomocą liczbowych indeksów tej metody HMS i HQA określono stopień przekształcenia siedlisk oraz oceniono ich naturalność. Warunki biotyczne oceniono na podstawie makrofitowej metody oceny rzek oraz makrobezkręgowców bentosowych. Makrobezkręgowce oznaczono do poziomu rodziny oraz obliczono wskaźniki jakości wody BMWP-Pl, ASPT i EPT\%. Na podstawie BMWP-Pl stwierdzono, że wody odcinka naturalnego zaliczają się do II klasy jakości, a przekształconego - do III klasy. Stwierdzono ponadto, że wskaźnik EPT\% był znacznie wyższy na odcinku nieprzekształconym. Ocena badanych odcinków na podstawie Makrofitowego Indeksu Rzecznego (MIR) wykazała, że na wartość liczbową tego wskaźnika stopień przekształcenia koryta nie miał większego wpływu. W obydwu przypadkach badane odcinki rzeki zaklasyfikowano do klasy II. Dodatkowo przeprowadzone zostały badania fizykochemiczne wody. Pomiędzy analizowanymi odcinkami badawczymi nie odnotowano istotnych różnic w jakości wody, które mogłoby wpływać na zróżnicowanie biocenotyczne tych stanowisk. Określono także zawartość części organicznych w osadach oraz określono charakterystyki uziarnienia. Dotychczasowe badania umożliwiły więc określenie pewnych relacji pomiędzy elementami 
abiotycznymi a elementami biotycznymi małej rzeki nizinnej i mogą stanowić bazę wyjściową do dalszych badań.

Stowa kluczowe: hydromorfologia cieku, makrobezkręgowce, makrofity, stan ekologiczny rzeki.

MS. received November 2011
Authors' address:

Karolina Sawa, Zbigniew Popek

Katedra Inżynierii Wodnej

Szkoła Główna Gospodarstwa Wiejskiego

ul. Nowoursynowska 159

02-776 Warszawa, Polska

e-mail:karolina_sawa@sggw.pl

e-mail:zbigniew_popek@sggw.pl 